Mussels Associated With Floodplain Channels Connected to the Apalachicola River

Barry S. Payne and Andrew C. Miller

June 2002

US Army Corps

of Engineers ${ }_{\circledast}$

Engineer Research and

Development Center

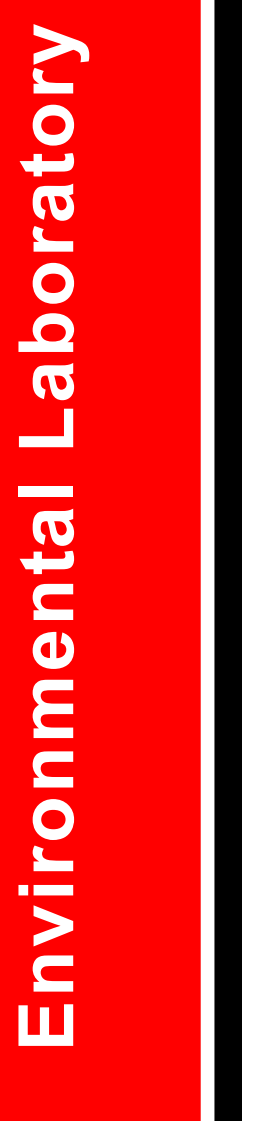


The contents of this report are not to be used for advertising, publication, or promotional purposes. Citation of trade names does not constitute an official endorsement or approval of the use of such commercial products.

The findings of this report are not to be construed as an official Department of the Army position, unless so designated by other authorized documents. 
ERDC/EL TR-02-13

June 2002

\title{
Mussels Associated With Floodplain Channels Connected to the Apalachicola River
}

by Barry S. Payne and Andrew C. Miller

\author{
Environmental Laboratory \\ U.S. Army Engineer Research and Development Center \\ 3909 Halls Ferry Road \\ Vicksburg, MS 39180-6199
}

Final report

Approved for public release; distribution is unlimited. 


\section{Contents}

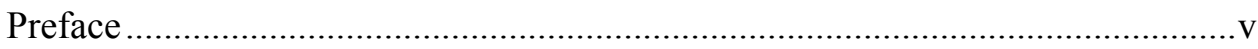

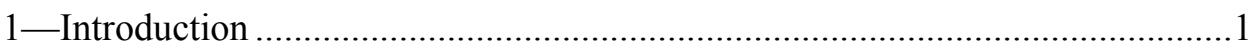

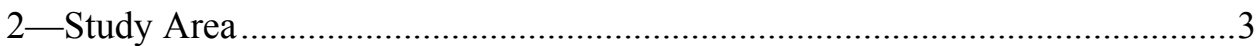

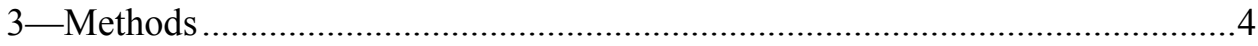

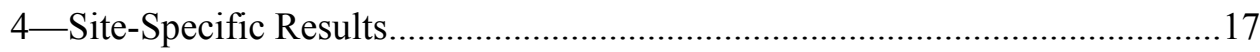

5-Composite Description of Mussel Community .........................................22

6-Mussel Relocation and Recommendations.............................................2

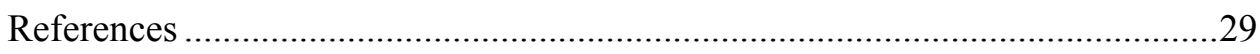

SF 298

\section{List of Figures}

Figure 1. Location of Waypoint 20, Apalachicola River, FL ........................ 7

Figure 2. Location of Waypoints 2 through 5, Apalachicola River, FL ........ 8

Figure 3. Map of Apalachicola River showing locations of Waypoints 1 and 6 through 8

Figure 4. Map of Apalachicola River showing locations of Waypoints 9 through 11

Figure 5. Map of Apalachicola River showing locations of Waypoints 12 through 16 and the relocation sites (Waypoints 28 and 29)....... 11

Figure 6. Map of Apalachicola River showing locations of Waypoints 17 through 19 12

Figure 7. Map of Apalachicola River showing locations of Waypoints 21 through 23 
Figure 8. Map of Apalachicola River showing locations of Waypoints 23 through 26 .

Figure 9. Map of Apalachicola River showing location of Waypoint 27 and origin of Apalachicola River at Jim Woodruff Dam

Figure 10. Map of Apalachicola River showing location of mussel relocation sites (Waypoints 28 and 29)

Figure 11. Number of species as a function of number of individuals collected at each location in the Apalachicola River where native mussels were found.

Figure 12. Size demography of Amblema neislerii collected in the Apalachicola River, 3-5 July 2001

Figure 13. Size demography of Elliptoideus sloatianus collected in the Apalachicola River, 3-5 July 2001 26

\section{List of Tables}

Table 1. Study sites with River Mile (RM), Waypoints (WP), Latitude, and Longitude.

Table 2. Community composition based on composite samples of mussels collected from all sites .................................................... 23

Table 3. Summary data on mussels collected at each site ......................... 24

Table 4. Summary information on mussels relocated to a transect between Waypoints 28 and 29 


\section{Preface}

This study was conducted for the U.S. Army Engineer District, Mobile, Mobile, AL, by the Environmental Laboratory (EL), U.S. Army Engineer Research and Development Center (ERDC), U.S. Army Corps of Engineers. Mainstream Diving, Inc., Paducah, KY, conducted the diving portion of the study. Assistance in the field was provided by Mr. William B. Green, University of Southern Mississippi, Hattiesburg, and Ms. Kathryn Barko, University of Wisconsin at Stevens Point. Dr. Andrew C. Miller, Aquatic Ecology and Invasive Species Branch (AEIB), Ecosystem Evaluation and Engineering Division (EEED), EL, was the diving inspector for this study.

During the conduct of this study, Dr. Edwin A. Theriot was Acting Director, EL; Dr. David J. Tazik was Chief, EEED; and Dr. Alfred F. Cofrancesco was Acting Chief, AEIB. Authors of this report were Drs. Barry S. Payne and Andrew C. Miller, AEIB.

At the time of publication of this report, the ERDC Commander and Executive Director was COL John W. Morris III, EN, and the Director was Dr. James R. Houston.

This report should be cited as follows:

Payne, B. A., and Miller, A. C. (2002). "Mussels associated with floodplain channels connected to the Apalachicola River," ERDC/EL TR-02-13, U.S. Army Engineer Research and Development Center, Vicksburg, MS.

The contents of this report are not to be used for advertising, publication, or promotional purposes. Citation of trade names does not constitute an official endorsement or approval of the use of such commercial products. 


\section{Introduction}

Deposition of sediment and debris at the mouths of many sloughs that empty into the Apalachicola River reduces connectivity between these tributaries and the river at low water. Such discontinuity is greatest at low flow (Light et al. 1998). Lack of confluence leads to stagnant conditions in the sloughs and tends to reduce water and sediment quality. Dredging of selected slough mouths may help restore aquatic habitat and enhance connectivity of tributaries that provide important refugia and spawning habitat for the diverse assemblage of fish in the Apalachicola River (see Light et al. 1998).

The Apalachicola River is within the range of several federally listed endangered and threatened species of freshwater mussels (Family: Unionidae). The region of North Florida, Southeast Alabama, and Southwest Georgia supports nearly 30 species of endemic freshwater mussels (Butler 1989, 1993). The high degree of endemism relates to the geographic separation of the more or less parallel rivers in this region that drain southward to the Gulf of Mexico. In addition to mussels, approximately 12 species of fish, 20 snails, and 24 crayfish are endemic to the region. Many of these endemic organisms are under consideration for listing as endangered or threatened. In accordance with the Endangered Species Act of 1973, as amended, personnel from the Mobile District, as well as resource agencies, are concerned that proposed dredging and disposal of sediments at the mouths of sloughs could negatively affect resident mussel populations.

The range of the following mussel species, listed in the Federal Register (Vol. 63, No. 50/Monday, March 16, 1998), includes the Apalachicola River:

Lampsilis subangulata - shiney-rayed pocketbook (endangered)

Amblema neislerii - fat threeridge (endangered)

Medionidus simpsonianus - Ocklockonee moccasinshell (endangered)

Medionidus penicillatus - Gulf moccasinshell (endangered)

Pleurobema pyriforme - oval pigtoe (endangered)

Elliptio chipolaensis - Chipola slabshell (threatened)

Elliptoideus sloatianus - purple bankclimber (threatened). 
Recent studies of historic and potential dredged material disposal sites in the Apalachicola River have established the presence of substantial populations of both the endangered A. neislerii and the threatened E. sloatianus (Miller 1998). 


\section{Study Area}

The Apalachicola River is a large alluvial river that flows south from its origin at Jim Woodruff Lake (built in 1954 at the confluence of the Chattahoochee and Flint rivers), across the Florida panhandle to the Gulf of Mexico. The river empties into Apalachicola Bay at Apalachicola, FL.

The Apalachicolan Region includes an area between the Escambia and Suwannee river systems and occupies southeast Alabama, southwest Georgia, and north Florida. Streams in this region that drain the Coastal Plain Physiographic Province are low gradient, and have beds comprised of sand, silty sand, mud, and some gravel (Butler 1989).

Mobile District personnel identified 28 sloughs that empty into the Apalachicola River between RM 13.2 and 105.1 as sites requiring mussel surveys to determine the presence and abundance of two endangered species, A. neislerii and E. sloatianus. The mouths of the sloughs and approximately 50-100 $\mathrm{m}$ upand downriver of the mouths were of interest due to potential dredging to remove deposited sediment and debris that tend to disconnect these sloughs from the river channel. The sections downriver of the sloughs were sampled to evaluate possible effects on freshwater mussels by the disposal of the dredged material taken from the slough mouths. Maintaining river connection provides aquatic resource benefits, allowing fish passage, spawning, and rearing. Maintaining connectivity also promotes flow that improves water and substratum quality. 


\section{Methods}

In late May and early July 2001, surveys were conducted to evaluate abundance and diversity of mussels at the 28 slough mouths listed by the Mobile District. The May study (29-31 May 2001) involved wading in shallow water to obtain mussels. A return trip during 3-5 July 2001 was made with a 4-person dive crew to allow divers to survey the same areas but to include deeper water at all locations.

Typically, searches by wading consisted of three individuals feeling the substratum for mussels for a period of 10 to 30 minutes each. Substratum was sandy; thus, tactile searches were likely to find even relatively small mussels. Asian clams, C. fluminea, 10-15 mm long, were easily obtained by this technique. At most locations, one person waded up the slough mouth and one each waded upand downriver of the mouth along the shallow littoral zone of the Apalachicola River itself. The mussel survey covered the entire slough mouth plus approximately 50-100 m up- and downriver. The intent was to examine not only the slough mouth that would be dredged, but also the section downriver where dredged material would be placed.

Dive surveys conducted in July repeated this pattern, except that the diver tended to work much farther farshore than was possible by wading. The survey boat was anchored at the vicinity of the mouth of the tributary located at the river mile where restoration was proposed. This is the position represented by the latitude/longitude coordinates of the mussel finds. Project dimensions were estimated from this location. The survey divers performed a tactile survey of the majority of the river bottom within these dimensions with the objective of surveying the majority of the area.

All native mussels found were placed in a mesh bag for identification at the end of each search. After identification, the mussels were replaced in the substratum upriver of the survey area. All A. neislerii or E. sloatianus found during the July survey (none were found in May) were measured for length to the nearest $0.01 \mathrm{~mm}$ using a digital caliper. A numbered bee tag was glued to each measured individual. These individuals were kept in mesh bags in fresh river water until they were relocated to a designated site (RM 73.3) away from any proposed dredging or disposal activity. Mussels were relocated along a transect between 30.398054 (latitude), 85.020002 (longitude) and 30.398059 (latitude), 85.020077 (longitude).

Latitude and longitude of all sites and other important locations were recorded with a hand-held global positioning system (GPS; Garmin GPS12XL 
Personal Navigator) (see Table 1, Figures 1-10). Typically, a waypoint was established where the right descending bank (RDB) of each slough connected to the Apalachicola River shoreline. All live endangered mussels were measured, marked, and placed along a transect between two closely adjacent nearshore locations (Figure 10). Maps for this report were produced from coordinates obtained in the field and information stored in Street Atlas Version 6.0. Based upon information provided by Garmin, Inc., an error of approximately 5-100 m can occur when using this equipment. Some errors can also occur when waypoints are plotted on maps that are slightly out of date (i.e., river channels often change over time). 


\begin{tabular}{|c|c|c|c|c|}
\hline \multicolumn{5}{|c|}{$\begin{array}{l}\text { Table } 1 \\
\text { Study Sites With River Mile (RM), Waypoints (WP), Latitude, and } \\
\text { Longitude }\end{array}$} \\
\hline Site & RM & WP & Latitude $(\mathrm{N})$ & Longitude (W) \\
\hline Marina Ramp & 4.0 & & 29.757744 & 85.019310 \\
\hline Humphrey Slough & 13.2 & 20 & 29.853871 & 85.021584 \\
\hline Kennedy Creek & 26.0 & 5 & 30.004398 & 85.062559 \\
\hline Battle Bend & 28.8 & 4 & 30.017283 & 85.100216 \\
\hline Douglas Slough \#1 & 30.1 & 3 & 30.023436 & 85.115113 \\
\hline Douglas Slough \#2 & 30.8 & 2 & 30.030988 & 85.122182 \\
\hline Moccasin Slough & 38.8 & 1 & 30.110969 & 85.139521 \\
\hline Hog Slough & 40.0 & 6 & 30.116800 & 85.130019 \\
\hline Swift Slough & 40.4 & 7 & 30.120751 & 85.131374 \\
\hline Glenn Landing Boat Ramp & 42.0 & & 30.131949 & 85.143077 \\
\hline Florida River & 43.2 & 8 & 30.145608 & 85.132389 \\
\hline Equiloxic Creek & 51.9 & 9 & 30.213837 & 85.098567 \\
\hline lamonia Lake & 55.8 & 10 & 30.249807 & 85.079200 \\
\hline Mary Slough & 58.5 & 11 & 30.272525 & 85.063138 \\
\hline Dirt Bridge Slough & 65.1 & 12 & 30.322785 & 85.047116 \\
\hline Sand Slough & 65.4 & 13 & 30.326203 & 85.045420 \\
\hline Baker Branch & 70.6 & 14 & 30.376367 & 85.036745 \\
\hline Lower Poloway Cutoff & 71.4 & 15 & 30.375848 & 85.024484 \\
\hline Upper Poloway Cutoff & 71.5 & 15 & 30.375034 & 85.026031 \\
\hline Old River Mouth & 72.9 & 16 & 30.394631 & 85.015537 \\
\hline Old River Head & 77.0 & 17 & 30.416050 & 85.032559 \\
\hline Blountstown Landing & 77.4 & & 30.423485 & 85.032538 \\
\hline Ramsey Landing & 80.2 & & 30.441030 & 84.986477 \\
\hline Kelly Branch & 81.3 & 19 & 30.447397 & 84.987065 \\
\hline Sweetwater Creek & 89.3 & 18 & 30.526025 & 84.988529 \\
\hline Rock Creek & 95.2 & 21 & 30.584147 & 84.942982 \\
\hline Sand Bar Creek & 95.3 & 22 & 30.586980 & 84.943388 \\
\hline Blue Spring Run & 98.2 & 23 & 30.614225 & 84.923319 \\
\hline Flat Creek & 99.5 & 24 & 30.625098 & 84.903387 \\
\hline Flat Creek & 100.5 & 25 & 30.638640 & 84.901836 \\
\hline Sinai Creek & 100.6 & 26 & 30.641635 & 84.900709 \\
\hline Mosquito Creek & 105.1 & 27 & 30.693002 & 84.860561 \\
\hline Hwy 90 Boat Ramp & 105.7 & & 30.700845 & 84.857209 \\
\hline
\end{tabular}




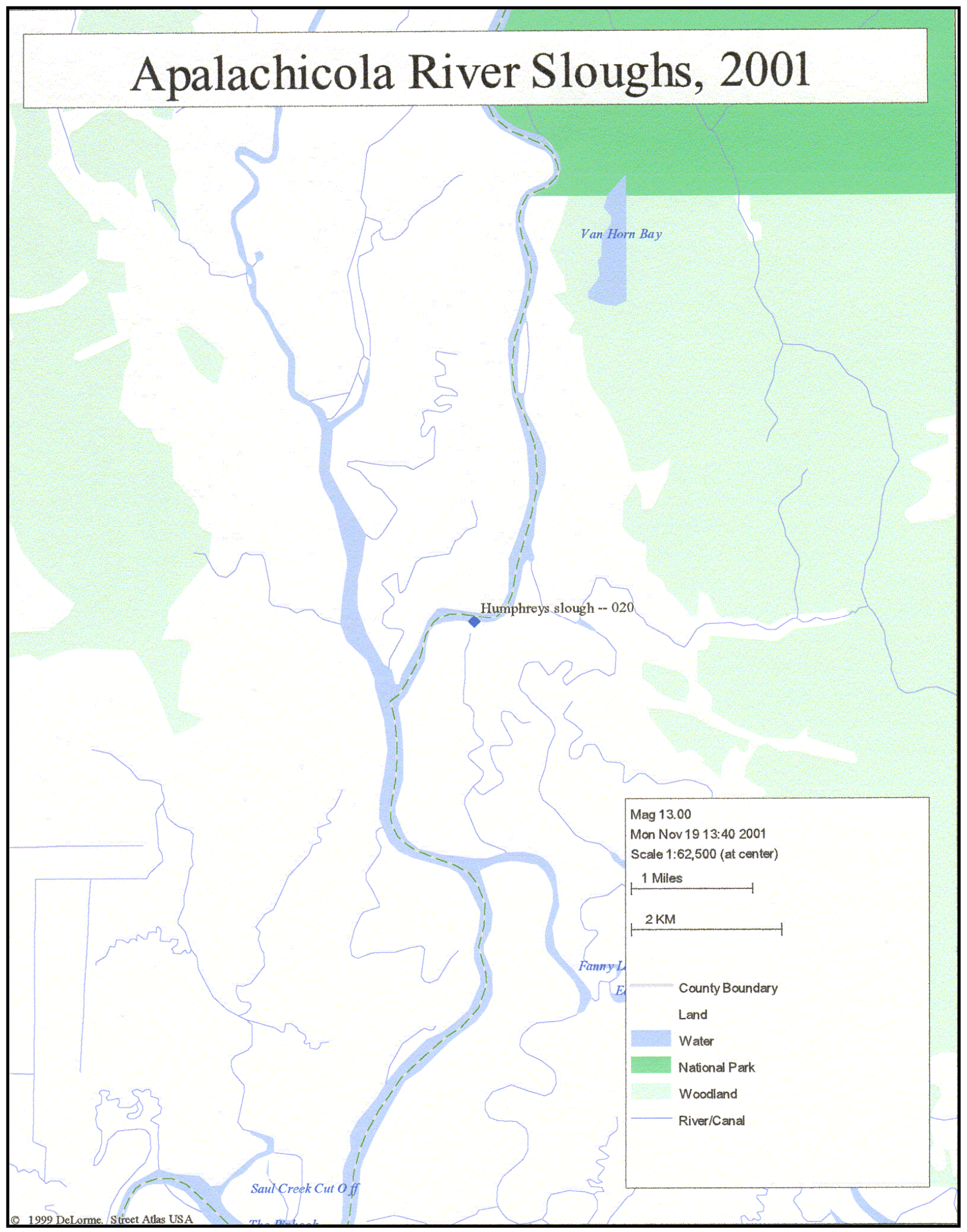

Figure 1. Location of Waypoint 20, Apalachicola River, FL 


\section{Apalachicola River Sloughs, 2001}

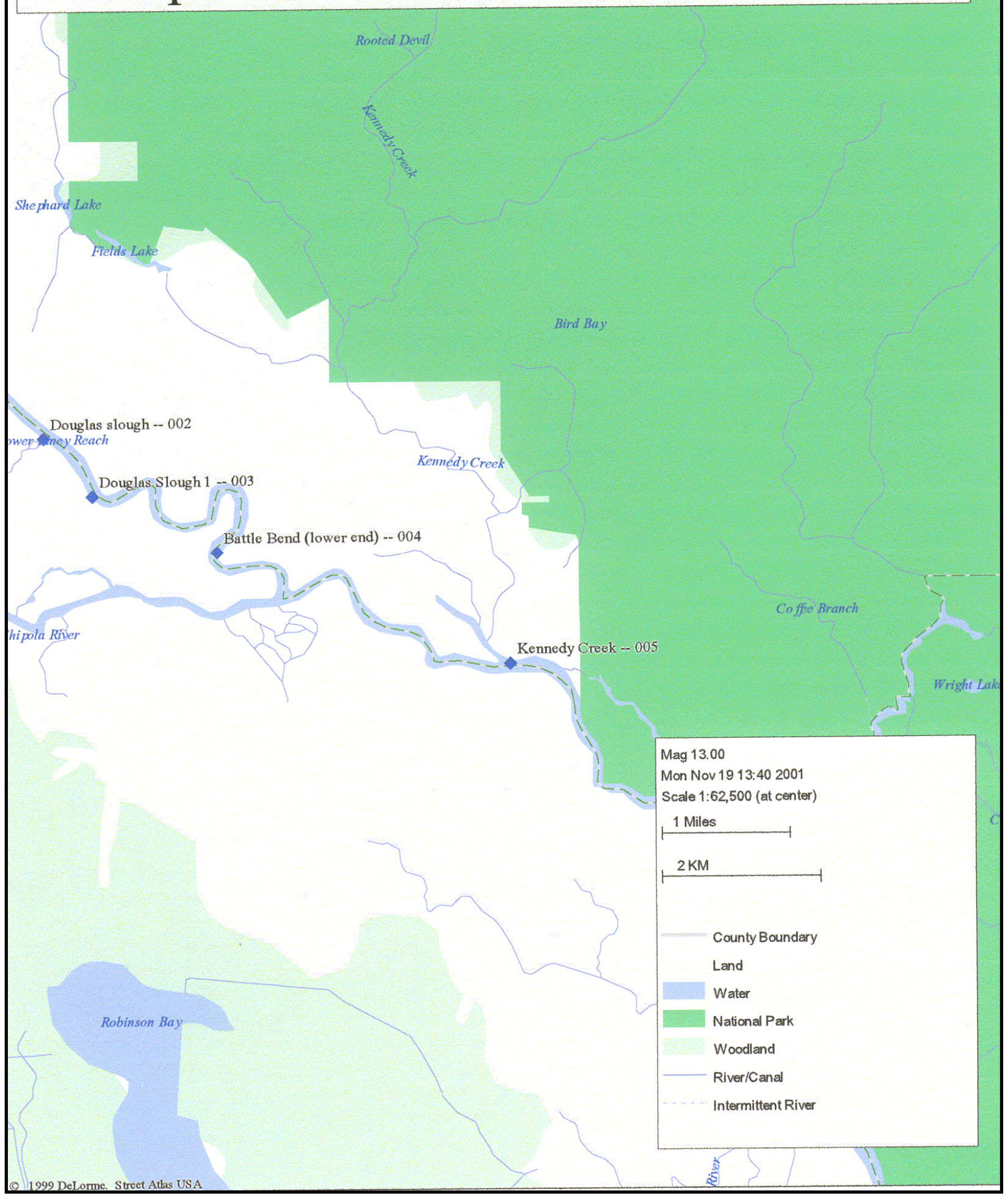

Figure 2. Location of Waypoints 2 through 5, Apalachicola River, FL 


\section{Apalachicola River Sloughs, 2001}

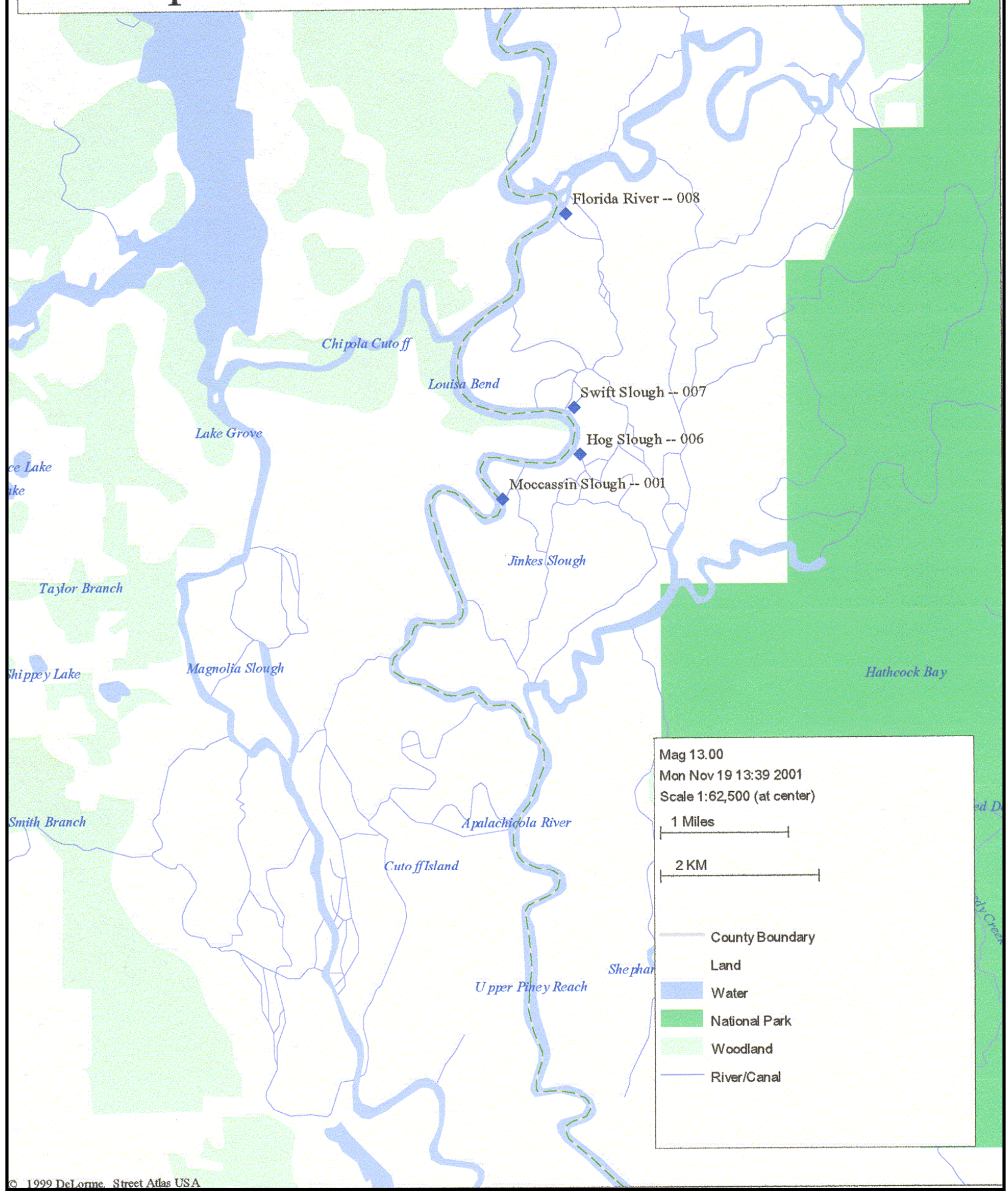

Figure 3. Map of Apalachicola River showing locations of Waypoints 1 and 6 through 8 


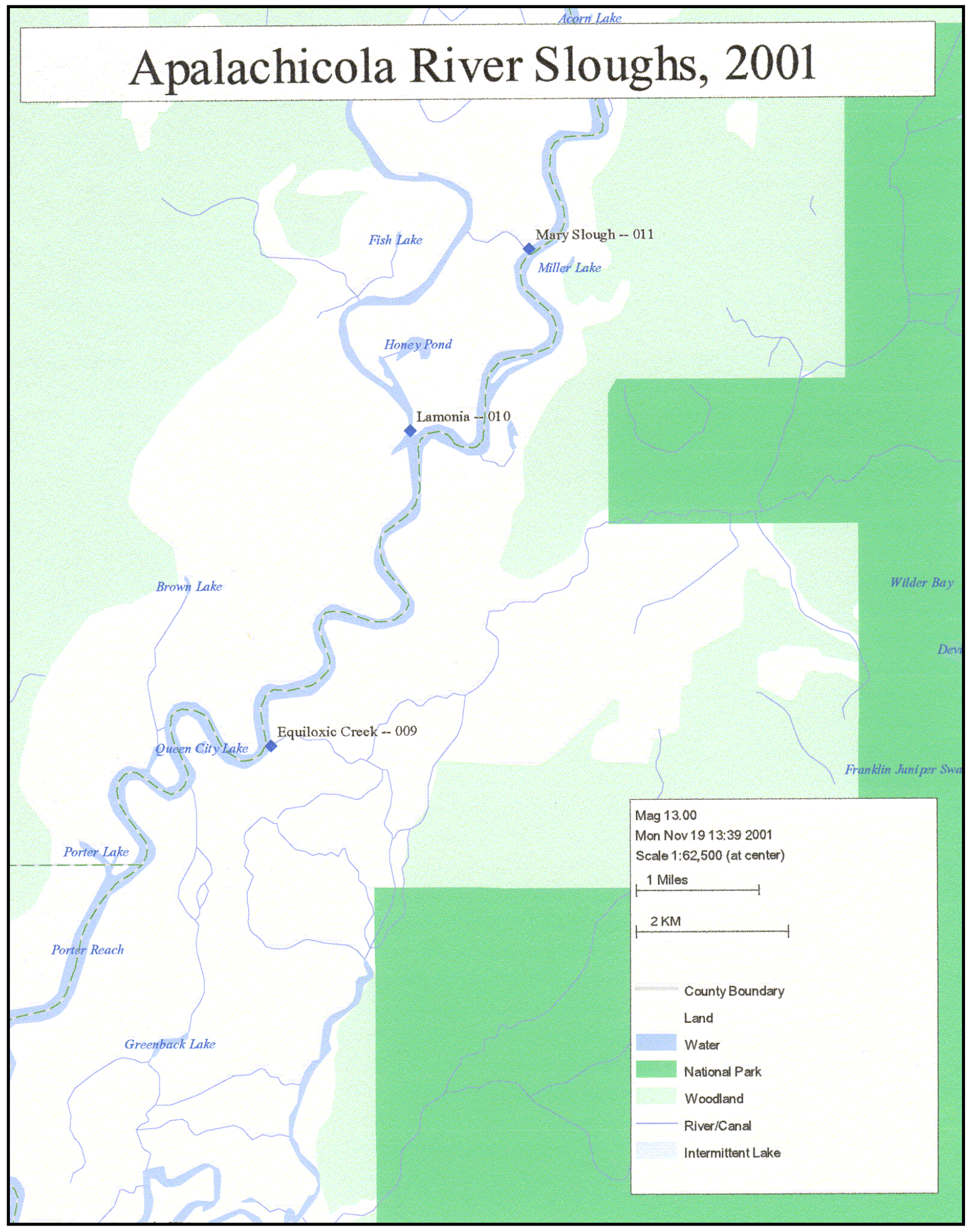

Figure 4. Map of Apalachicola River showing locations of Waypoints 9 through 11 


\section{Apalachicola River Sloughs, 2001}

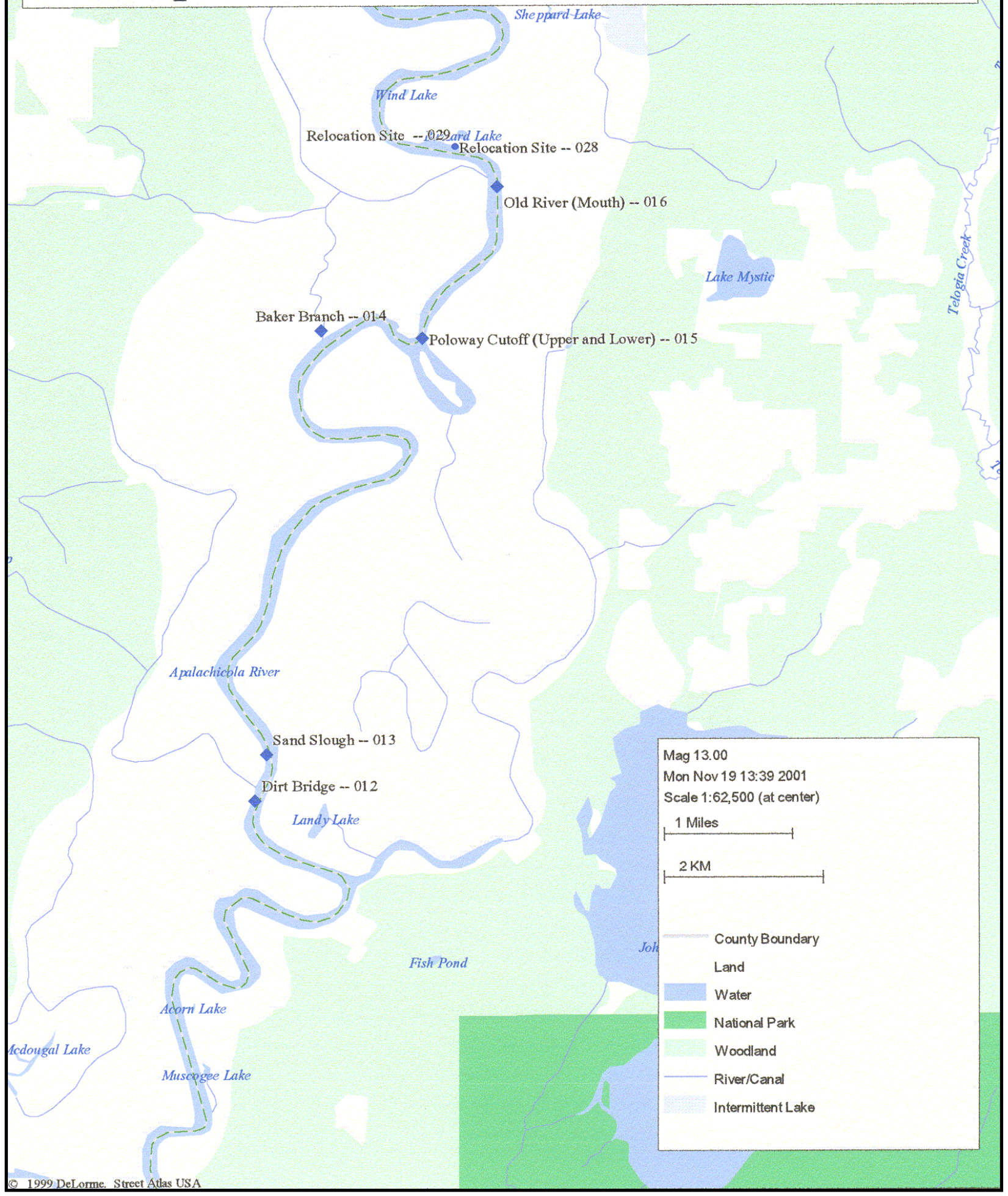

Figure 5. Map of Apalachicola River showing locations of Waypoints 12 through 16 and the relocation sites (Waypoints 28 and 29) 


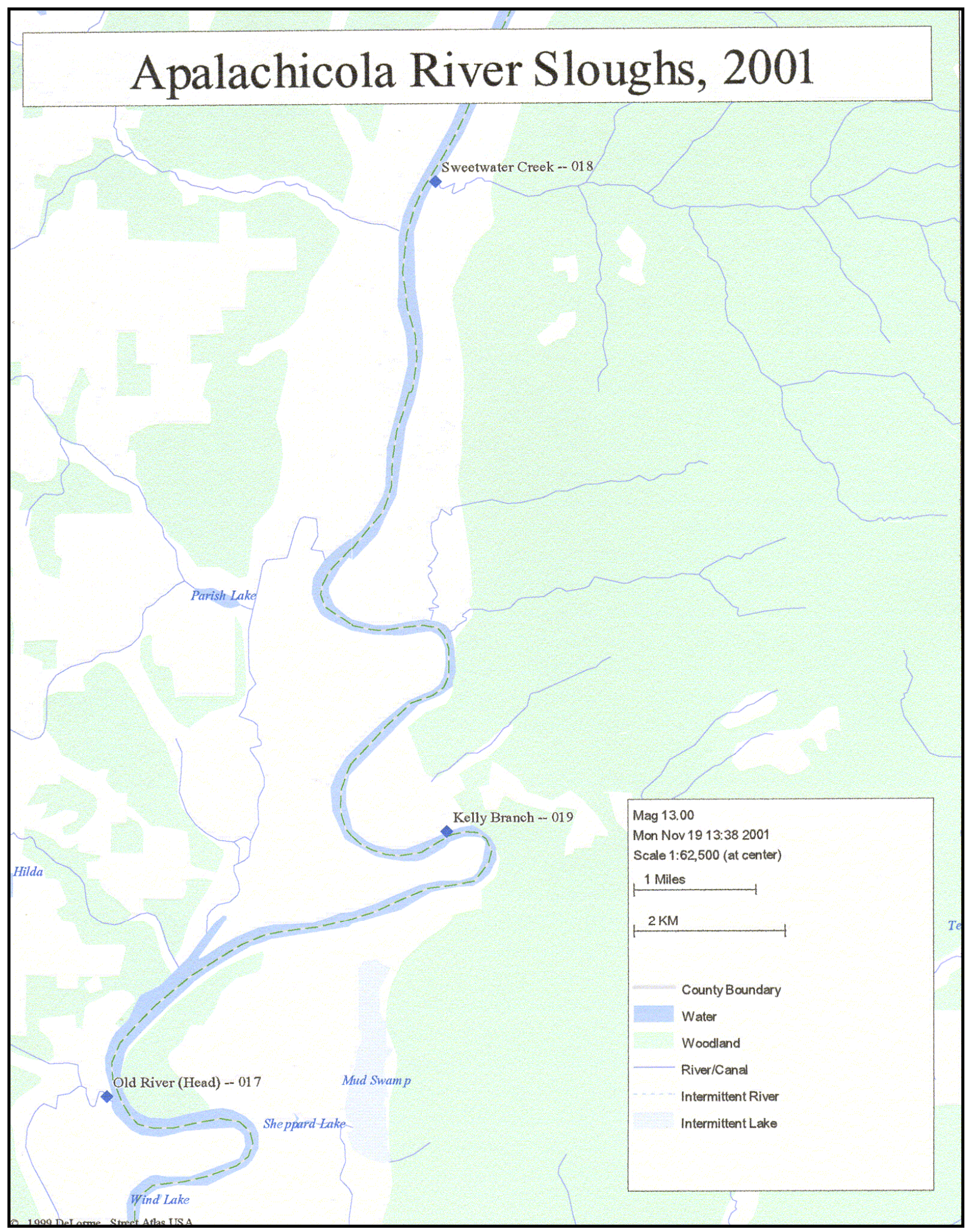

Figure 6. Map of Apalachicola River showing locations of Waypoints 17 through 19 


\section{Apalachicola River Sloughs, 2001}

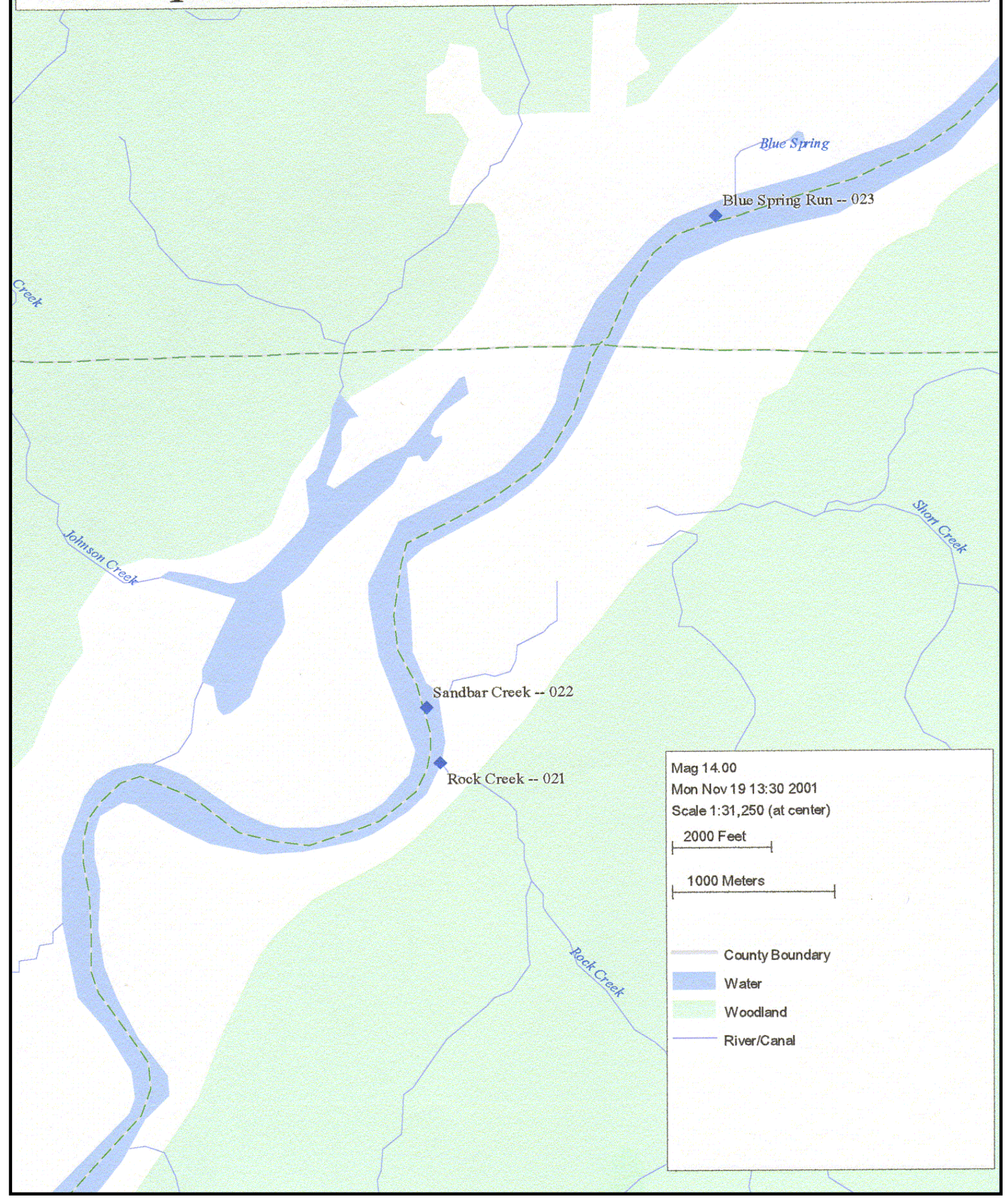

Figure 7. Map of Apalachicola River showing locations of Waypoints 21 through 23 


\section{Apalachicola River Sloughs, 2001}

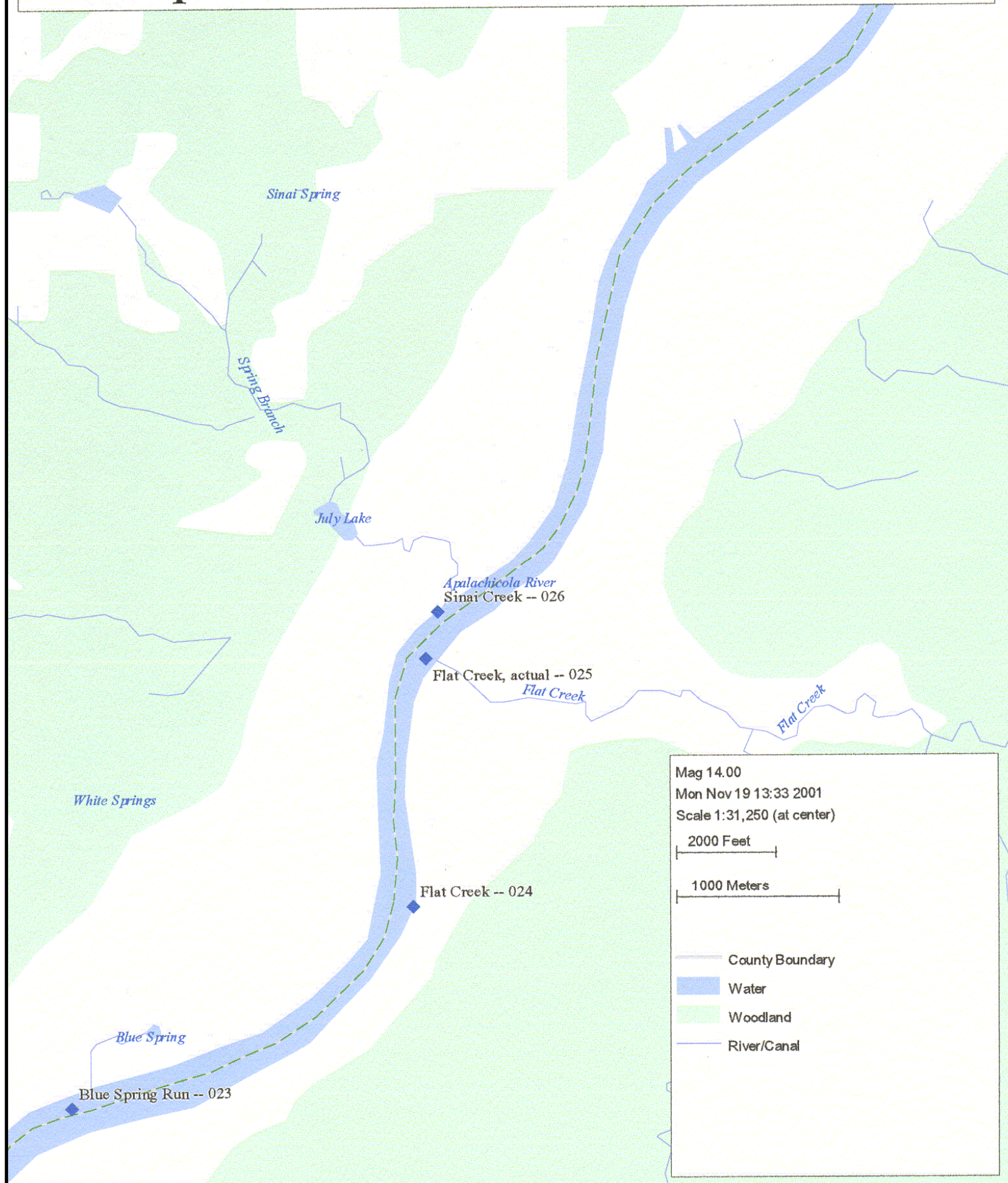

Figure 8. Map of Apalachicola River showing locations of Waypoints 23 through 26 


\section{Apalachicola River Sloughs, 2001}

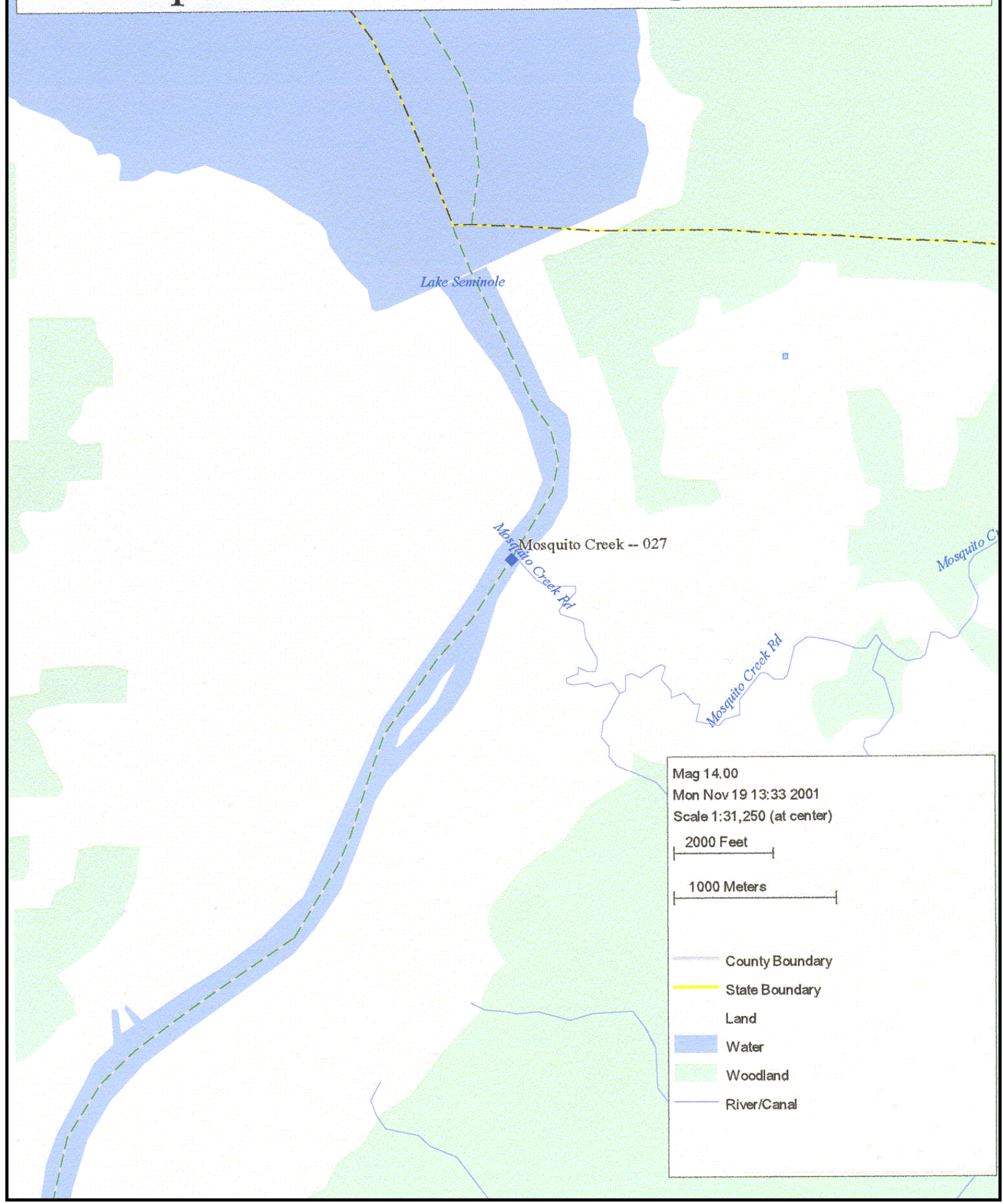

Figure 9. Map of Apalachicola River showing location of Waypoint 27 and origin of Apalachicola River at Jim Woodruff Dam 


\section{Apalachicola River Sloughs, 2001}

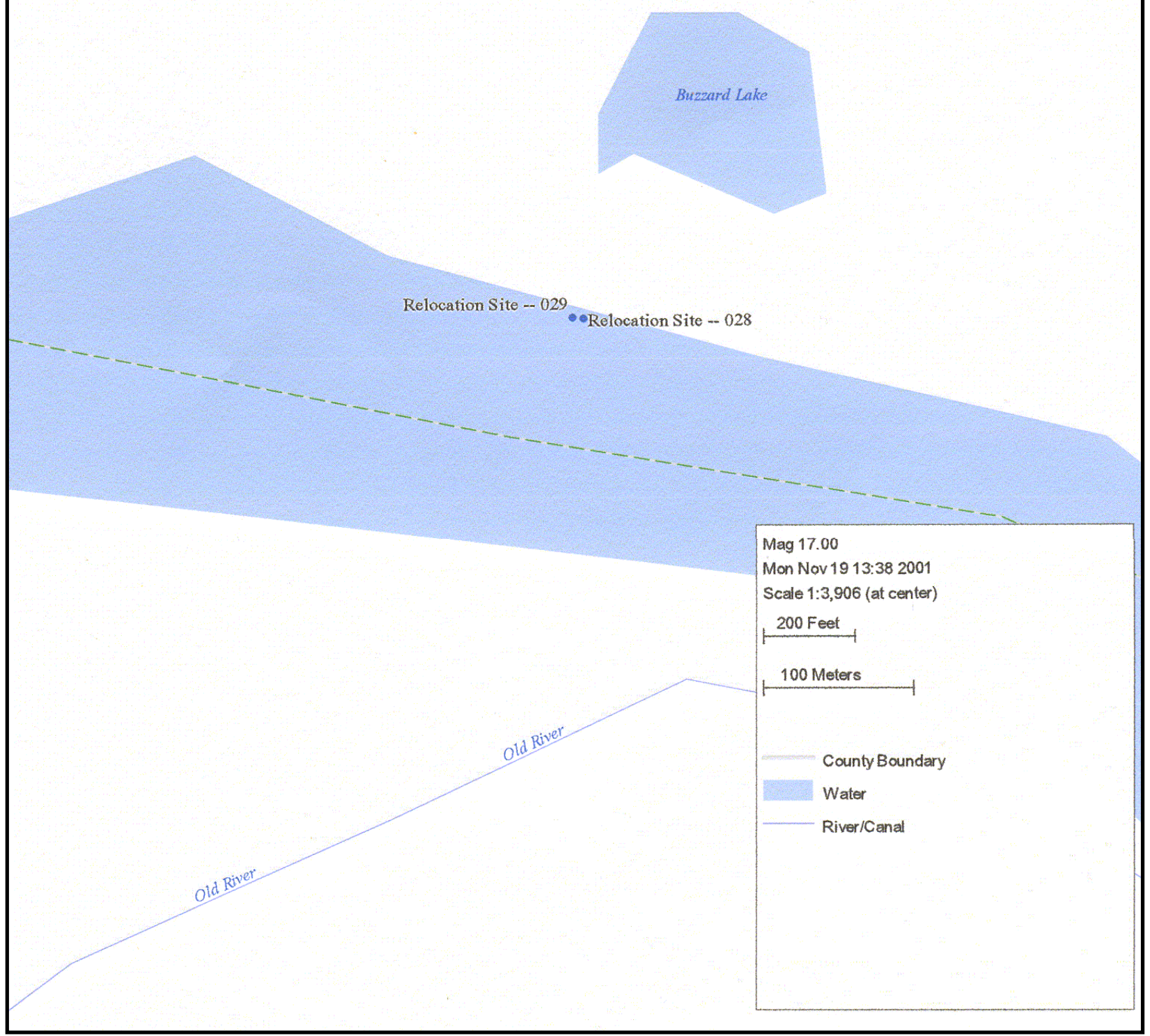

Figure 10. Map of Apalachicola River showing location of mussel relocation sites (Waypoints 28 and 29) 


\section{Site-Specific Results}

Brief descriptions of habitat and mussels encountered at each site, ordered from downriver to downriver, are provided in the following paragraphs.

Humphrey's Slough (RM 13.2, Left Descending Bank (LDB)). A total of 19 native mussels were collected at this site. On 31 May, 11 Glebula rotundata and a single Lampsilis teres were collected during 40 minutes of search by wading. The small $G$. rotundata were collected near shore, often among or near root wads. All mussels collected while wading were in water less than $1.5-\mathrm{m}$ deep. Substratum consisted of firm sand and clay among root wads along the shore. The mouth of the slough was approximately 3- to 4-m wide, and the slough slightly upriver was approximately $20-\mathrm{m}$ wide. A large amount of woody debris was piled (by flow) along the downstream end of the slough.

A 20-minute diving survey in early July yielded four Elliptio crassidens, one L. teres, and two Megalonaias nervosa. The diver searched slightly deeper water in July, which probably resulted in his collection of larger mussels of other species.

Kennedy Creek (RM 26.0, LDB). Investigators found no mussels at this location during either a 45-minute search by wading in late May or a 15-minute dive survey in early July. This large creek had deposited at its mouth an expansive bar of very coarse sand that extended at least $200 \mathrm{~m}$ into the Apalachicola River. The mouth of the creek was 200 -m wide but only $0.5-\mathrm{m}$ deep or less on 30 May 2001. Many C. fluminea were found in the sandbar, but the substratum was not suitably stable for longer-lived native mussels.

Battle Bend (RM 28.8, LDB). A total of seven mussels were collected in May during a 45-minute search by wading. None were found during a 20-minute dive search in July. All seven mussels were G. rotundata measuring 3- to 5-cm long. The mouth of this slough was approximately $30-\mathrm{m}$ wide in May, and was connected to the river by a 1-m-wide cut through sediment deposited at the mouth. Substratum was sand and silt that appeared suitably stable for mussels. Only C. fluminea were found in abundance.

Douglas Slough \#1 (RM 30.1, RDB). This site was choked by large snags at its mouth and along the downstream confluence with the river. In May a large number of old $C$. fluminea and a few unionid shells were found in muck and leaf litter deposited among the snags. No live mussels or $C$. fluminea were obtained during 45 minutes of wading, however. This small slough was barely confluent with the river in May. 
In contrast, a diver searching for 20 minutes in deeper water both up- and downriver of the slough in July obtained 8 species and 42 unionids. $M$. nervosa dominated that collection $(\mathrm{n}=18)$. Thirteen $E$. sloatianus and three $A$. neislerii were found. In addition, four E. crassidens, two G. rotundata, one Elliptio icterina, and one L. teres were collected.

Douglas Slough \#2 (RM 30.8, RDB). A total of 54 unionids were collected by wading for 60 minutes at this site in May. Many C. fluminea were also found. As in other wading surveys, the nearshore assemblage of mussels was dominated by $G$. rotundata $(\mathrm{n}=47)$. Other mussels collected in May included five L. teres, one E. complanata, and one Lampsilis hydiana. On 30 May the slough was not connected to the river. The slough mouth consisted of a series of small pools full of large woody debris. Substratum consisted of sand with silt. All mussels were collected while wading in the river at the mouth of the creek and downriver of the mouth along the bank slope.

In July a diver collected 50 mussels of 6 species in 20 minutes, working slightly farshore of sites where wading surveys had been conducted in May. Glebula rotundata $(\mathrm{n}=20)$ and E. icterina $(\mathrm{n}=19)$ shared dominance in that collection. Eight $A$. neislerii were obtained. Single specimens of $E$. complanata, $E$. crassidens, and $L$. teres were also found.

Moccasin Slough (RM 38.3, LDB). This slough was connected to the river by a 3-m-wide channel, and had many small, partly submerged willows at its mouth. A few live $C$. fluminea were found but no living freshwater mussels. Substratum was fine sand with some clay and was not suitably stable for unionids.

Hog Slough (RM 40.0, LDB). No mussels were obtained at this site in May by wading ( 30 minutes) or in July by diving ( 20 minutes). This site was located along a very steep, scoured clay bank of the Apalachicola River and offered little suitable habitat for mussels. The slough was less than 0.2-m deep where it connected to the river. Pools approximately $1-\mathrm{m}$ deep occurred slightly upriver in the slough. The substratum in the pools consisted of muck with much large woody debris. Investigators found no mussels, $C$. fluminea, or shell debris in these pools. The river was not searchable by wading in May, and the diver in July found no mussels in the river near the tributary's mouth or in the slough itself.

Swift Slough (RM 40.4, LDB). No mussels were found in May by wading (60 minutes); a single G. rotundata was found in July by diving (23 minutes). This was a sinuous pooled slough with moderate to dense large woody debris. The slough was deep in May ( $>2 \mathrm{~m})$. Substratum consisted of sand and silt that seemed suitably stable for mussels. A single old shell of an A. neislerii was found on the shore. Previous surveys near this site have indicated presence of several $A$. neislerii; none were obtained in the present study.

Florida River (RM 43.2, LDB). This large river had many willows along each shore where it connected to the Apalachicola River. The channel was deep (2-3 m) and wide (>100 m). Substratum was scoured fine sand. Many $C$.

fluminea were found, but no mussels or shells were seen during 45 minutes of 
wading in May. The dive survey in July yielded eight unionids, including a single A. neislerii. The other seven individuals were G. rotundata.

Equiloxic Creek (RM 51.9, LDB). This medium-sized slough yielded no mussels by wading in May (30 minutes) or diving in July (15 minutes). The channel was deep $(>2 \mathrm{~m})$ with willows along the downstream confluence with the Apalachicola River. Substratum was medium sand. Many C. fluminea were found here.

Iamonia Lake (RM 55.8, RDB). This slough joined the river along a steep cut bank. The scoured bank provided no suitable habitat for mussels. The slough was deep $(>2 \mathrm{~m})$ and in late May essentially a large pool with steep banks. Some C. fluminea but no unionids were found during a 15-minute wading search in the slough in May. A 20-minute dive survey in July recovered three mussels - two G. rotundata and one Quincuncina infucata.

Mary Slough (RM 58.5, RDB). The mouth of this small slough was approximately $10-\mathrm{m}$ wide. The slough was barely connected to the river in May; depth of the connecting channel was only $0.1 \mathrm{~m}$. The pool upriver of the sand plug was approximately $2-\mathrm{m}$ deep and had a substratum of consolidated sand. Sixty minutes of wading yielded no mussel but many $C$. fluminea. A short dive survey in July yielded no mussels.

Dirt Bridge Slough (RM 65.1, RDB). This 2-m-wide slough was not confluent with the river in May. Substratum was fine sand with silt. Waders searched a 20-m-long and 1-m-deep pool in the slough, as well as the adjacent sandy slope. A 45-minute search yielded no mussels but many small $C$. fluminea. A 5 -minute dive survey in July yielded no mussels. The sandy habitat in the river at this location was not suitably stable to support unionid populations.

Sand Slough (RM 65.4, RBD). This slough was a dry depression that angled into the river behind a huge sandbar. The sand was coarse, unstable underfoot, and formed a very low gradient slope into the river. A 45-minute survey in May yielded no mussels or $C$. fluminea. The same results occurred after a 5-minute dive survey in July.

Baker Branch (RM 70.6, RDB). This slough entered the river along a very steep scoured bank. A 30-minute wading survey was limited to the slough. The slough was 20-m wide and 1-m deep. Substratum was coarse sand, clay, and muck with a distinct hydrogen sulfide odor. No native mussels or $C$. fluminea were obtained from this poor habitat. A 20-minute dive survey in July yielded the same result.

Lower Poloway Cutoff (RM 71.4, LDB). This site was a very broad shoal of coarse sand at an old disposal site. No native mussels and few $C$. fluminea were found during a 30-minute wading survey in May. However, a 20-minute dive survey in July in deeper water yielded 70 mussels of 5 species. The dominant was $E$. crassidens $(\mathrm{n}=29)$. Also abundant were $G$. rotundata $(\mathrm{n}=16)$ and Q. infucata $(\mathrm{n}=11)$. The endangered $E$. sloatianus $(\mathrm{n}=8)$ was moderately abundant. Six M. nervosa were found. 
Upper Poloway Cutoff (RM 71.5, LDB). A 20-minute dive survey here yielded no mussels. This site was shallow and erosional; the sandy substratum was not suitably stable for unionids.

Old River Mouth (RM 72.9, RDB). This was an erosional site where a broad shoal of coarse sand formed in the river near the slough mouth (a dry sand channel in May). Corbicula fluminea were scattered at low density; a single native mussel (L. teres) was found during a 60-minute wading survey in May. A 20 -minute dive survey in July yielded no additional mussels in this relatively poor habitat.

Old River Head (RM 77.0, RDB). This slough was deep (2 m) with much woody debris. Substratum was fine sand and clay. During wading in May, a few $C$. fluminea but no live mussels or shells were found in 45 minutes. A 20 -minute dive survey in July yielded two shells (M. nervosa and E. crassidens), many live C. fluminea, but no live unionids.

Kelly Branch (RM 81.3, LDB). This narrow slough (2- to 3-m wide) was confluent with the river and had a substratum of fine sand with some silt and clay. C. fluminea were very dense at this site, and included two or three cohorts in an age-structured population. A 30-minute survey by wading in May yielded no mussels. Likewise, a 10-minute dive survey in July resulted in no mussels being found.

Sweetwater Creek (RM 89.3, LDB). This slough was along a steep, scoured bank that provided little mussel habitat. The slough itself was a series of slackwater pools that were approximately $2-\mathrm{m}$ deep in May. A sand plug divided the slough from the river. Large woody debris was abundant. No mussels and only a few $C$. fluminea were found during 30 minutes of wading in May. A 20-minute dive survey in July yielded no mussels but several dead shells. The diver described high flow and shifting sand near the channel at this location.

Rock Creek (RM 95.2, LDB). This 5-m-wide slough emptied into the river along a depositional shoreline of the river just downriver of a sandbar. The sand was medium to fine with muck and clay. Many shells but no live C. fluminea were found and no native mussels were encountered during a 30-minute wade in May. Similarly, no mussels were found during a 20-minute dive in July. The substratum encountered during the dive survey graded from rock and gravel near the river thalweg to sand with patches of clay nearshore.

Sandbar Creek (RM 95.3, LDB). The mouth of this slough was 1-m wide and 0.12-m deep, and emptied into the river along a sandy disposal area and sandbar. Substratum was sand and muck. Habitat was similar to that at Rock Creek. Neither a 30-minute wading survey in May nor a 20-minute dive survey in July yielded any mussels. The diver encountered sand in the river channel, grading to silt sand nearshore.

Blue Spring (RM 98.2, RDB). This was a moderately steep-banked slough with a trapezoidal channel. Water was cool and probably spring-fed. The slough was approximately $1.2-\mathrm{m}$ deep and 2- to $4-\mathrm{m}$ wide. The substratum in the slough and river was sand and silt. A few (mostly large) C. fluminea shells were found, 
but no live mussels were encountered during a 30-minute wading survey in July. A 20-minute dive survey in July yielded no mussels; the diver encountered somewhat coarser substratum (pea gravel and shifting coarse sand) farshore of areas that could be waded.

Flat Creek (RM 99.5, LDB). This site was near a concrete boat ramp along the LDB of the slough. The slough was $20-\mathrm{m}$ wide and $1.5-\mathrm{m}$ deep at its mouth. Deeper water $(>2 \mathrm{~m})$ occurred upriver of the sand plug at the slough's mouth. Substratum was fine sand and muck. Old shells but no live $C$. fluminea were encountered. No unionids were recovered by wading in May (30 minutes) or by diving in July (20 minutes).

Flat Creek (RM 100.5, LDB). This was a dry slough. The mouth was at the downstream end of a dike field in the river. $C$. fluminea shells and fine sand comprised the substratum near the mouth of the slough. A broad shallow sand bar provided poor mussel habitat. No unionids were found by wading in May (30 minutes) or by diving in July (20 minutes). Water velocity was moderately high in the river at this location.

Sinai Creek (RM 100.6, LDB). This spring-fed (cool) slough had a substratum of soft sand and muck with much detritus. The slough was $20-\mathrm{m}$ wide and $0.7-\mathrm{m}$ deep. No mussels were found by wading (30 minutes) or by diving (20 minutes). The diver described sand and gravel with silt over lots of dead C. fluminea shells in the river at this location.

Mosquito Creek (RM 105.1, LDB). This site was associated with sunken barges and other industrial debris near an industrial site along the LDB. A 20-minute dive survey in July yielded no mussels; the search was conducted upriver of the industrial area. Substratum was gravel and rock. 


\section{Composite Description of Mussel Community}

In summary, the mussel community associated with the mouths of sloughs in the Apalachicola River was dominated by G. rotundata (44.314\%) (Table 2). Four other species comprised more than $5 \%$ of the fauna: E. crassidens $(14.9 \%), M$. nervosa $(10.2 \%)$, E. icterina $(7.8 \%)$, and the threatened E. sloatianus $(7.8 \%)$. The federally endangered species $A$. neislerii comprised $4.7 \%$ of the total sample from all slough mouths. Other species obtained were $Q$. infucata $(4.7 \%)$, L. teres $(3.9 \%)$, L. hydiana $(0.78 \%)$, and E. complanata $(0.78 \%)$. In addition, the Asiatic clam $C$. fluminea was common but not sampled in a fashion to allow accurate estimation of relative abundance.

Most sites did not support native mussels. Mussels were obtained at only 7 of the 28 sloughs surveyed. Furthermore, all but $11.5 \%$ of the 181 mussels collected came from just 3 sites. These sites were Douglas Slough \#1, Douglas Slough \#2, and Lower Poloway Cutoff, at RM 30.1, 30.8, and 71.5, respectively. A total of 33 individuals of the 2 endangered species $A$. neislerii and E. sloatianus were obtained. All but one of these individuals came from one of those three sites that yielded $89.5 \%$ of all mussels. At Douglas Slough \#1, 3 A. neislerii and 13 E. sloatianus were collected. At Douglas Slough \#2, eight $A$. neislerii were collected. Eight $E$. sloatianus were obtained at Lower Poloway Cutoff. A single A. neislerii was obtained at the mouth of the Florida River (RM 43.2).

Mussels obtained per collecting effort ranged from 0 to 3.5 individuals per minute (Table 3). Even at the best locations for mussels, populations were not dense. Only at Douglas Slough \#1, Douglas Slough \#2, and Lower Poloway Cutoff did the number of mussels collected per minute exceed 1.0. Values at these three sites ranged from 2.1 to 3.5 individuals per minute. Considering only those seven locations at which mussels were obtained, the number of species was a linear function of the number of individuals collected (Figure 11). Richness estimates at these 7 sites ranged from 1 to 8 species; abundance ranged from 1 to 70 individuals. Species obtained in previous studies but not in the present effort include Pyganodon heardi, Pyganodon grandis, Toxolasma parvus, Utterbackia imbecillis, and Villosa villosa. Ordinarily, the rate at which new species are obtained in a survey decreases as more individuals are collected.

Although only 12 A. neislerii were collected during these 2 surveys, 1 was less than 20-mm long (Figure 12). Thus, there was evidence of recent recruitment 
of this species in the Apalachicola River. The modal size of adult A. neislerii was 55 to $65 \mathrm{~mm}$. In contrast, recent recruits were not included among the $21 \mathrm{E}$. sloatianus collected in this study (Figure 13). Individuals ranged from 100- to 180-mm long. The smallest mussel collected measured $109 \mathrm{~mm}$. Most adults were 130 - to 170 -mm long.

\begin{tabular}{|c|c|c|}
\hline \multicolumn{3}{|c|}{$\begin{array}{l}\text { Table } 2 \\
\text { Community Composition Based on Composite Samples of Mussels } \\
\text { Collected From All Sites }\end{array}$} \\
\hline Species & Number Collected & Percent Abundance \\
\hline Amblema neislerii & 12 & 4.69 \\
\hline Elliptio complanata & 2 & 0.78 \\
\hline Elliptio crassidens & 38 & 14.84 \\
\hline Elliptio icterina & 20 & 7.81 \\
\hline Elliptoideus sloatianus & 21 & 8.20 \\
\hline Glebula rotundata & 113 & 44.14 \\
\hline Lampsilis teres & 10 & 3.91 \\
\hline Megalonaias nervosa & 26 & 10.16 \\
\hline Pyganodon heardi & 0 & 0.00 \\
\hline Pyganodon grandis & 0 & 0.00 \\
\hline Quincuncina infucata & 12 & 4.69 \\
\hline Toxolasma parvus & 0 & 0.00 \\
\hline Utterbackia imbecillis & 0 & 0.00 \\
\hline Villosa villosa & 0 & 0.00 \\
\hline Lampsilis hydiana & 2 & 0.78 \\
\hline Total Mussels & 256 & \\
\hline $\begin{array}{l}\text { Total Species } \\
\end{array}$ & 10 & \\
\hline
\end{tabular}




\begin{tabular}{|c|c|c|c|c|}
\hline \multicolumn{5}{|c|}{$\begin{array}{l}\text { Table } 3 \\
\text { Summary Data on Mussels Collected at Each Site } \\
\text { (CPUE = mussels collected per minute) }\end{array}$} \\
\hline Site (River Mile, Waypoint) & Mussels & Species & Minutes & CPUE \\
\hline Humphrey Slough $(13.2,20)$ & 19 & 4 & 60 & 0.32 \\
\hline Kennedy Creek $(26.0,5)$ & 0 & 0 & 60 & 0.00 \\
\hline Battle Bend $(28.8,4)$ & 7 & 1 & 65 & 0.11 \\
\hline Douglas Slough \#1 $(30.1,3)$ & 42 & 8 & 65 & 0.65 \\
\hline Douglas Slough \#2 $(30.8,2)$ & 104 & 7 & 80 & 1.30 \\
\hline Moccasin Slough $(38.8,1)$ & 0 & 0 & 67 & 0.00 \\
\hline Hog Slough $(40.0,6)$ & 0 & 0 & 50 & 0.00 \\
\hline Swift Slough $(40.4,7)$ & 1 & 1 & 83 & 0.01 \\
\hline Florida River $(43.2,8)$ & 8 & 2 & 65 & 0,12 \\
\hline Equiloxic Creek $(51.9,9)$ & 0 & 0 & 42 & 0.00 \\
\hline lamonia Lake $(55.8,10)$ & 3 & 2 & 35 & 0.09 \\
\hline Mary Slough $(58.5,11)$ & 0 & 0 & 65 & 0.00 \\
\hline Dirt Bridge Slough $(65.1,12)$ & 0 & 0 & 50 & 0.00 \\
\hline Sand Slough $(65.4,13)$ & 0 & 0 & 50 & 0.00 \\
\hline Baker Branch $(70.6,14)$ & & 0 & 50 & 0.00 \\
\hline Lower Poloway Cutoff $(71.5,15)$ & 70 & 5 & 35 & 2.00 \\
\hline Upper Poloway Cutoff $(71.5,15)$ & 0 & 0 & 35 & 0.00 \\
\hline Old River Mouth $(72.9,16)$ & 1 & 1 & 80 & 0.01 \\
\hline Old River Head $(77.0,17)$ & 0 & 0 & 65 & 0.00 \\
\hline Kelly Branch $(81.3,19)$ & 0 & 0 & 40 & 0.00 \\
\hline Sweetwater Creek $(89.3,18)$ & 0 & 0 & 50 & 0.00 \\
\hline Rock Creek $(95.2,21)$ & 0 & 0 & 50 & 0.00 \\
\hline Sand Bar Creek $(95.3,22)$ & 0 & 0 & 50 & 0.00 \\
\hline Blue Spring Run $(98.2,23)$ & 0 & 0 & 50 & 0.00 \\
\hline Flat Creek $(99.5,24)$ & 0 & 0 & 50 & 0.00 \\
\hline Flat Creek (on map) $(100.5,25)$ & 0 & 0 & 50 & 0.00 \\
\hline Sinai Creek $(100.6,26)$ & 0 & 0 & 50 & 0.00 \\
\hline Mosquito Creek $(105.1,27)$ & 0 & 0 & 50 & 0.00 \\
\hline Total & 255 & 10 & 1542 & 0.17 \\
\hline
\end{tabular}




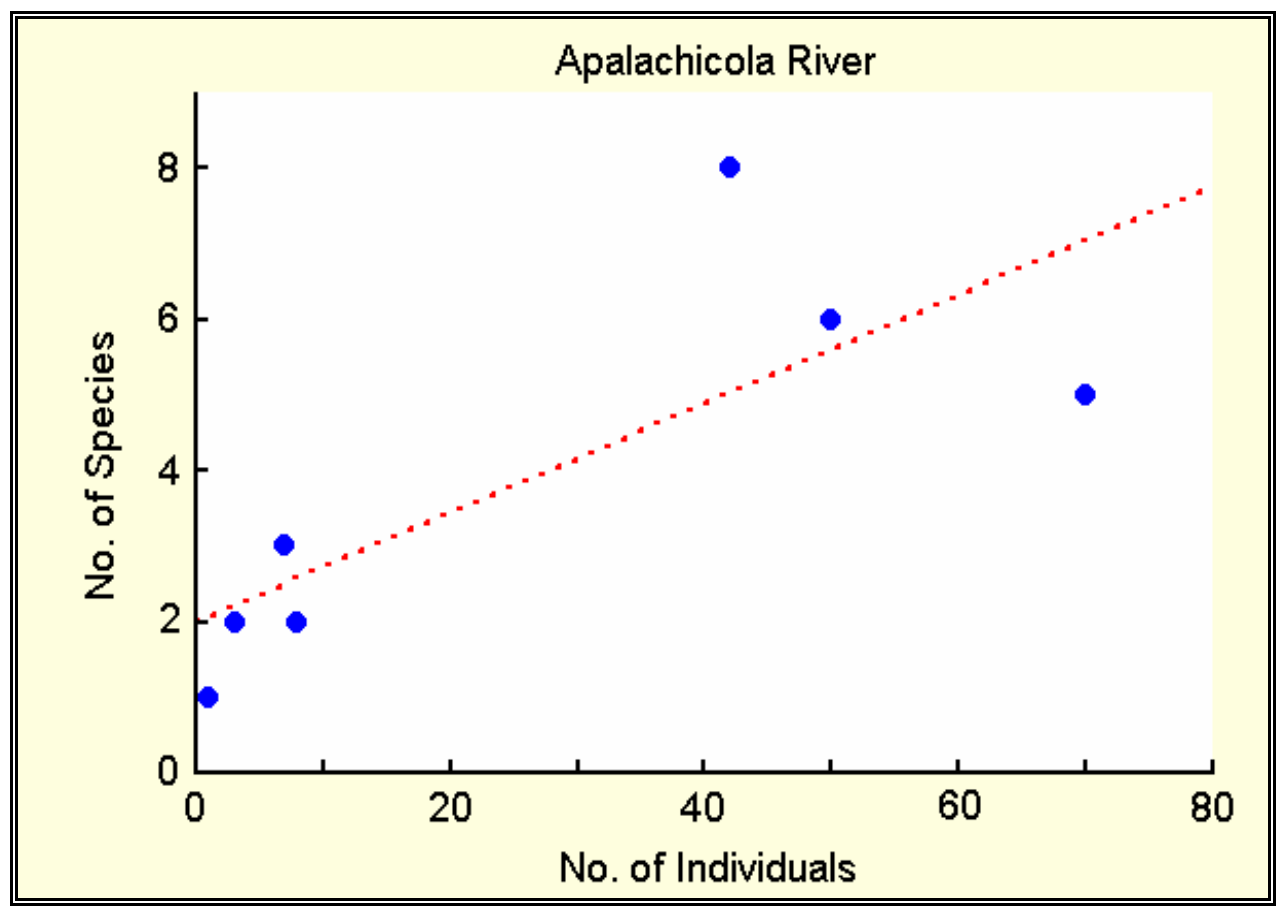

Figure 11. Number of species as a function of number of individuals collected at each location in the Apalachicola River where native mussels were found

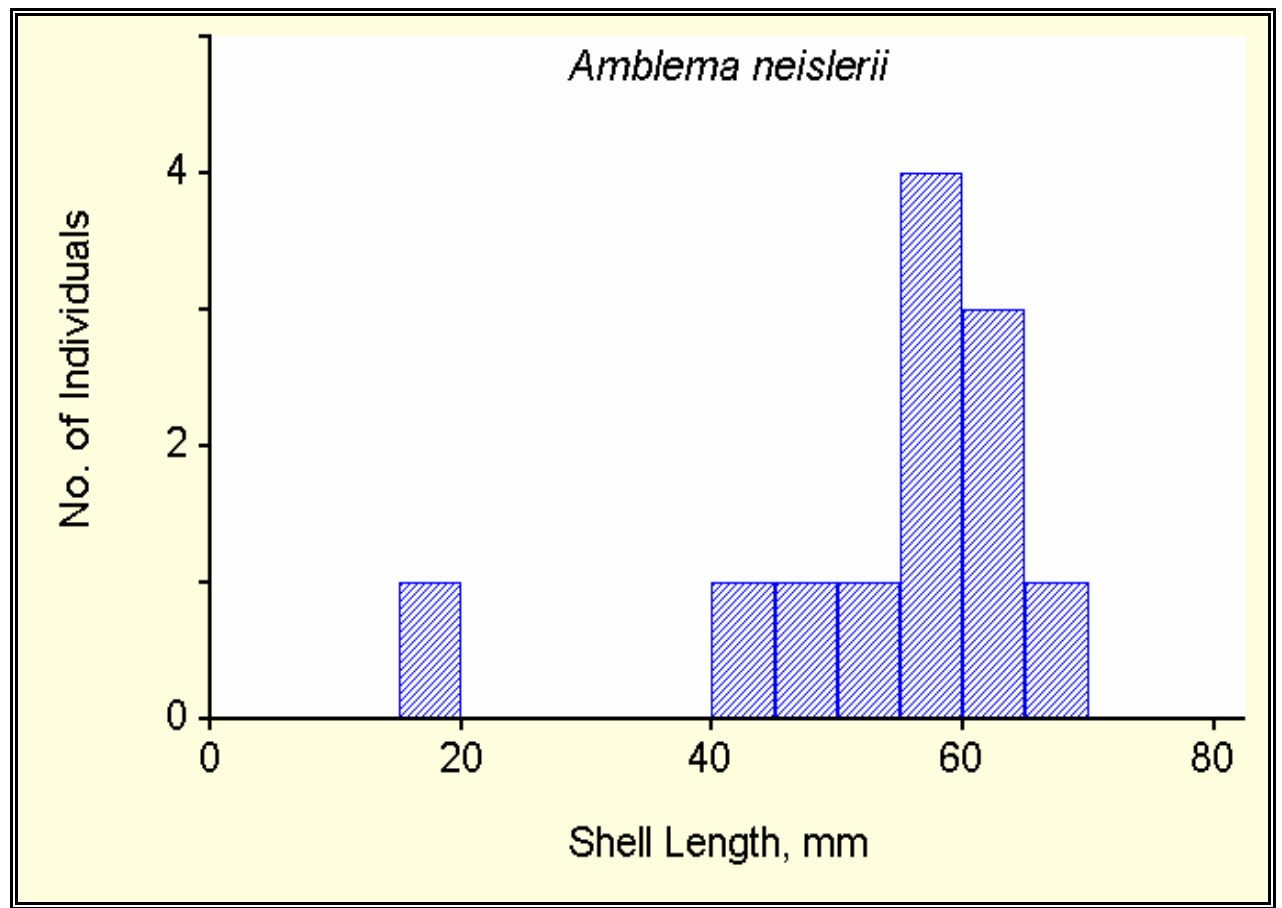

Figure 12. Size demography of Amblema neislerii collected in the Apalachicola River, 3-5 July 2001 


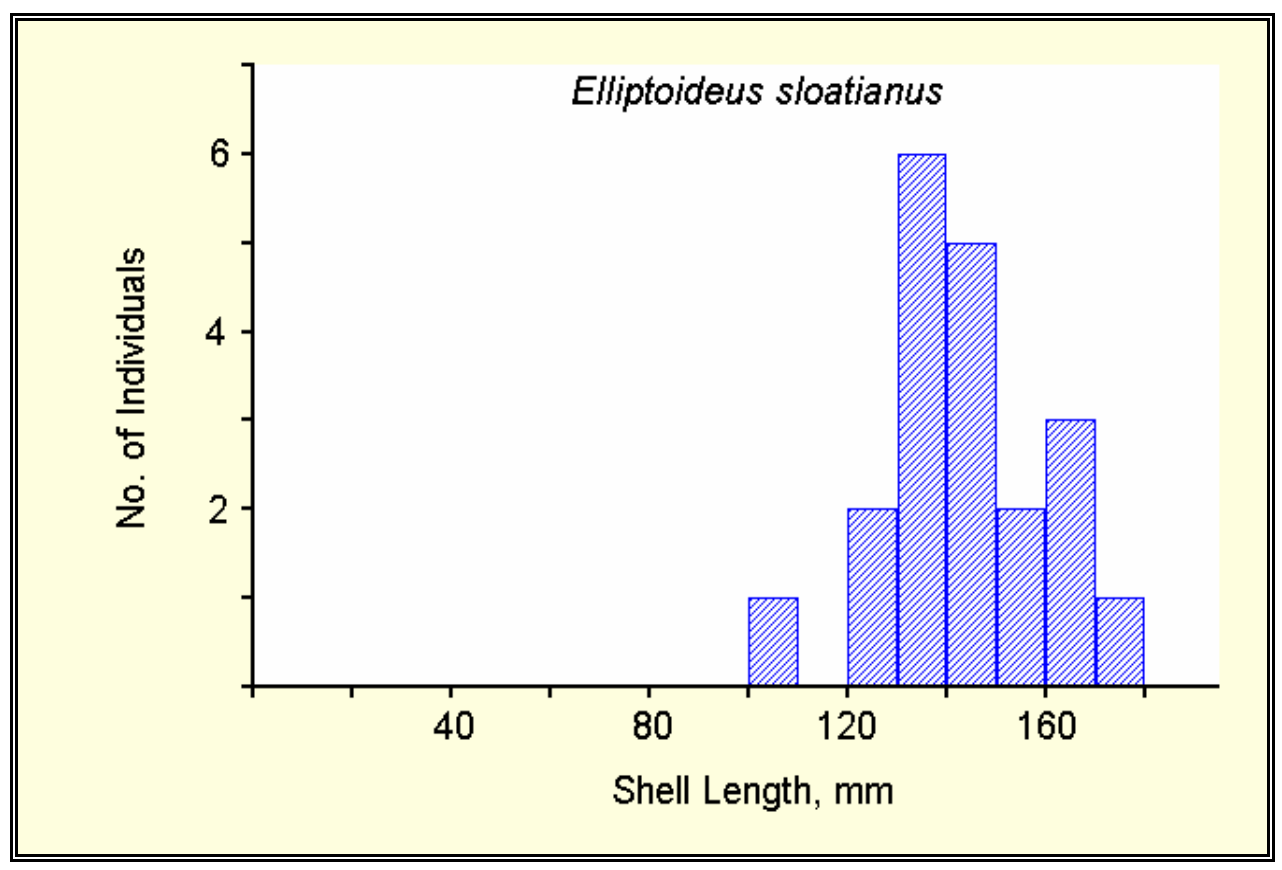

Figure 13. Size demography of Elliptoideus sloatianus collected in the Apalachicola River, 3-5 July 2001 


\section{Mussel Relocation and Recommendations}

All marked and measured A. neislerii and E. sloatianus were carefully placed by divers into the substratum at the relocation area, between Waypoints 28 and 29 (Figure 10). Mussels were placed, on 5 July 2001, at a depth of approximately $3 \mathrm{~m}$ and approximately $10 \mathrm{~m}$ from shore along the LDB. Table 4 provides data on individuals' identifying numbers and their measured lengths. Estimates of recapture success and individual growth rates should be possible by retrieving and measuring the marked individuals along this transect.

The results of this survey indicate that extreme caution should be exercised concerning any proposed dredging or disposal operations in the vicinity of the mouths of four tributaries. These are Douglas Slough \#1, Douglas Slough \#2, and Lower Poloway Cutoff, where mussels are moderately abundant and A. neislerii, E. sloatianus, or both are present. Although mussels were not abundant at the mouth of the Florida River, a single $A$. neislerii was obtained at that site and is noteworthy with respect to future dredging or disposal operations. 


\begin{tabular}{|c|c|c|c|}
\hline \multicolumn{4}{|c|}{$\begin{array}{l}\text { Table } 4 \\
\text { Summary Information on Mussels Relocated to a Transect Between } \\
\text { Waypoints } 28 \text { and } 29\end{array}$} \\
\hline Species & $\begin{array}{l}\text { Waypoint } \\
\text { of Origin }\end{array}$ & I.D. No. & Length, mm \\
\hline A. neislerii & 3 & 35 & 59.38 \\
\hline A. neislerii & 3 & 53 & 61.98 \\
\hline A. neislerii & 3 & 26 & 58.13 \\
\hline A. neislerii & 2 & 39 & 62.4 \\
\hline A. neislerii & 2 & 63 & 62.37 \\
\hline A. neislerii & 2 & 49 & 66.47 \\
\hline A. neislerii & 2 & 88 & 56.51 \\
\hline A. neislerii & 2 & 51 & 56.44 \\
\hline A. neislerii & 2 & 41 & 52.72 \\
\hline A. neislerii & 2 & 31 & 43.32 \\
\hline A. neislerii & 2 & 67 & 46.48 \\
\hline A. neislerii & 8 & 45 & 19.46 \\
\hline E. sloatianus & 3 & 1 & 108.52 \\
\hline E. sloatianus & 3 & 10 & 139.09 \\
\hline E. sloatianus & 3 & 24 & 137.55 \\
\hline E. sloatianus & 3 & 2 & 121.92 \\
\hline E. sloatianus & 3 & 11 & 132.22 \\
\hline E. sloatianus & 3 & 72 & 143.14 \\
\hline E. sloatianus & 3 & 4 & 129.43 \\
\hline E. sloatianus & 3 & 9 & 135.77 \\
\hline E. sloatianus & 3 & 27 & 143.67 \\
\hline E. sloatianus & 3 & 90 & 159.33 \\
\hline E. sloatianus & 3 & 95 & 142.78 \\
\hline E. sloatianus & 3 & 17 & 132.58 \\
\hline E. sloatianus & 3 & 3 & 131.61 \\
\hline E. sloatianus & 15 & 20 & 159.36 \\
\hline E. sloatianus & 15 & 23 & 140.52 \\
\hline E. sloatianus & 15 & 61 & 144.44 \\
\hline E. sloatianus & 15 & 38 & 169.50 \\
\hline E. sloatianus & 15 & 55 & 168.31 \\
\hline E. sloatianus & 15 & 97 & 162.42 \\
\hline E. sloatianus & 15 & 7 & 173.40 \\
\hline E. sloatianus & 15 & 64 & 160.30 \\
\hline
\end{tabular}




\section{References}

Butler, R. S. (1989). "Distributional records for freshwater mussels (Bivalvia: Unionidae) in Florida and south Alabama, with zoogeographic and taxonomic notes." Walkerana 3(10), 239-261.

Butler, R. S. (1993). "Results of a status survey for 8 freshwater mussels (Bivalvia: Unionidae) endemic to eastern gulf slope drainages of the Apalachicolan Region of southeast Alabama, southwest Georgia, and north Florida." Status Report Prepared by U.S. Fish and Wildlife Service, Jacksonville, FL.

Light, H. M., Darst, M. R., and Grubbs, J. W. (1998). “Aquatic Habitats in Relation to River Flow in the Apalachicola River Floodplain, Florida." U.S. Geological Survey Professional Paper 1594. ISBN 0-607-89269-2.

Miller, A. C. (1998). An Analysis of Freshwater Mussels (Unionidae) at Dredged Material Disposal Areas in the Apalachicola River, Florida. Technical Report EL-98-16. U.S. Army Engineer Waterways Experiment Station, Vicksburg, MS. 


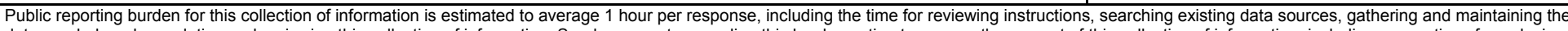

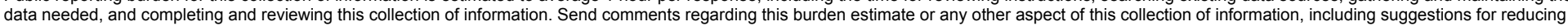

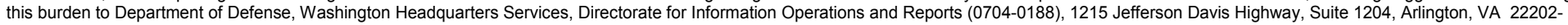

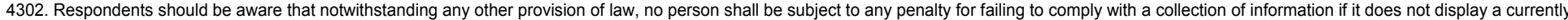
valid OMB control number. PLEASE DO NOT RETURN YOUR FORM TO THE ABOVE ADDRESS.
1. REPORT DATE (DD-MM-YYYY)
2. REPORT TYPE
3. DATES COVERED (From - To)

June 2002

4. TITLE AND SUBTITLE

Final report

Mussels Associated With Floodplain Channels Connected to the Apalachicola River

5a. CONTRACT NUMBER

5b. GRANT NUMBER

5c. PROGRAM ELEMENT NUMBER

6. AUTHOR(S)

5d. PROJECT NUMBER

Barry S. Payne and Andrew C. Miller

5e. TASK NUMBER

5f. WORK UNIT NUMBER

\section{PERFORMING ORGANIZATION NAME(S) AND ADDRESS(ES)}

8. PERFORMING ORGANIZATION REPORT NUMBER

U.S. Army Engineer Research and Development Center

Environmental Laboratory

ERDC/EL TR-02-13

3909 Halls Ferry Road

Vicksburg, MS 39180-6199

\section{SPONSORING / MONITORING AGENCY NAME(S) AND ADDRESS(ES)}

10. SPONSOR/MONITOR'S ACRONYM(S)

U.S. Army Engineer District, Mobile

P.O. Box 2288

Mobile, AL 36628-0001

11. SPONSOR/MONITOR'S REPORT NUMBER(S)

\section{DISTRIBUTION / AVAILABILITY STATEMENT}

Approved for public release; distribution is unlimited.

\section{SUPPLEMENTARY NOTES}

\section{ABSTRACT}

Searches for native mussels (Bivalvia: Unionidae) were conducted at the mouths of 28 tributaries (including sloughs, old ox-bows, and creeks) of the Apalachicola River, FL from 30-31 May and again from 3-5 July 2001. During the May survey, samples were collected by wading in shallow water. In July, a diver equipped with surface compressed air conducted sampling that included deeper water not accessible by wading. Total survey time per site (May and July combined) ranged from 40 to 80 minutes. Mussels were found at only 9 of 28 sites. Furthermore, 216 of the total 255 individuals collected were found at only three sites - Douglas Slough \#1, Douglas Slough \#2, and Lower Poloway Cutoff (an old ox bow). Overall, mussels were obtained at a rate of only 0.17 individuals per minute. At the three sites yielding most mussels, however, this rate ranged from 0.65 to 2.00 individuals per minute. At no other location did the rate of catch exceed 0.35 mussels per minute. Emphasis was on presence and abundance of endangered and threatened species. Two such species occurred. The threatened species, Amblema neislerii, was found at three locations (Douglas Sloughs \#1 and \#2 and Florida River). The endangered species Elliptoideus sloatianus was obtained at Douglas Slough \#2 as well as Lower Poloway Cutoff. The four sites at which one or both of these species were obtained, especially those three sites with moderately high mussel abundance, are noteworthy with respect to proposed maintenance dredging operations to restore or enhance connectivity of tributaries with the main channel of the river.

\section{SUBJECT TERMS}

Amblema neislerii

Apalachicola River
Freshwater mussels

Elliptoideus sloatianus
Tributary inlets

\begin{tabular}{|c|c|c|c|c|c|}
\hline \multicolumn{3}{|c|}{ 16. SECURITY CLASSIFICATION OF: } & \multirow{2}{*}{$\begin{array}{l}\text { 17. LIMITATION } \\
\text { OF ABSTRACT }\end{array}$} & $\begin{array}{l}\text { 18. NUMBER } \\
\text { OF PAGES }\end{array}$ & \multirow{2}{*}{$\begin{array}{l}\text { 19a. NAME OF RESPONSIBLE PERSON } \\
\begin{array}{l}\text { 19b. TELEPHONE NUMBER } \\
\text { (include area code) }\end{array}\end{array}$} \\
\hline $\begin{array}{l}\text { a. REPORT } \\
\text { UNCLASSIFIED }\end{array}$ & $\begin{array}{l}\text { b. ABSTRACT } \\
\text { UNCLASSIFIED }\end{array}$ & $\begin{array}{l}\text { c. THIS PAGE } \\
\text { UNCLASSIFIED }\end{array}$ & & 34 & \\
\hline
\end{tabular}

Standard Form 298 (Rev. 8-98)

Prescribed by ANSI Std. 239.18 